\title{
TRANSFORMATION:
}

\section{TRANSCENDENCE OR TRANSCULTURATION? THE MANY FACES OF CUBAN SANTERIA}

\author{
ADRIANH. HEARN
}

\section{NTRODUCTION}

In May 2002, as I was nearing the end of an eighteen-month stay in Cuba, I was invited to attend an artistic performance of popular traditions in Santiago de Cuba. As with folkloric recitals in hundreds of hotels, cabarets, cultural centres and nightclubs throughout the island, the spotlight focused on the most exotic, visually stimulating aspects of the AfroCuban religion Santería. It was a night of drumming, dancing, spirit possessions and, to the fascinated shock of many spectators, an animal sacrifice. The program for the performance, printed in English and Spanish, noted the central importance of these ritual activities to the practice of Santería in Cuba.

The following week I returned to the house of Miguel, a priest of Santería and my principal percussion teacher, with whom I had lived for 12 months in Havana. When Miguel saw the program from the performance, he commented that the facts it presented about the deities of Santería were inconsistent with the religion's spiritual teachings. But, to my surprise, he also laughed and said that to get away with this, the performance directors must be adept salespeople and true cabrones (literally 'bastards', though used in Cuba to signify cunning). Miguel dealt frequently with foreigners, from percussion students and anthropologists, to filmmakers and tour operators impressed with his lively explanations of Santería folklore.

But Miguel also had a substantial local religious following. He owned a set of sacred batá drums, consecrated by the renowned Pancho Quinto, and his house operated as a centre of religious activity in Old Havana, drawing a wide range of relatives and friends into a network of community support. The ceremonial gatherings that took place at his house maintained the spiritual and material well-being of participants: the pork, chicken, and goat meat used in ceremonial offerings was divided and shared among participants, and 'derechos' (fees) were paid to those who helped facilitate these occasions.

This kind of attention to social welfare has been central to the practice of AfroCuban religions since the establishment of mutual aid societies called cabildos in the sixteenth and seventeenth centuries. ${ }^{1}$ Through the economic crisis of the 1990s, grassroots social support has remained an important focus of Santería communities and networks, in some instances drawing them into collaboration with state urban development institutions. ${ }^{2}$ But some commentators argue that this historic 
capacity for collective action, which depends on strong and loyal networks of community support, is eroding with the religion's recent commercial renaissance. Rogelio Martínez Furé, Miguel Barnet, Carlos Moore, and others note that the appearance of sacred ceremonial actions in folklore cabarets and hotel nightclubs is trivialising and diluting the religion's social and spiritual cohesion. ${ }^{3}$

Foreign interest in Afro-Cuban religious exotica has swelled and subsided over the centuries, peaking prominently between 1920 and 1940, ${ }^{4}$ but the expansion of tourism in Cuba since the early 1990s has generated unprecedented commercial appeal around Santería and other historic Cuban traditions. According to Eusebio Leal, Old Havana's equivalent of Mayor and the director of the Office of the Historian of the City:

Tourism is here to stay, and it will increase a hundredfold when the blockade is abolished. North Americans want to come here because we have something they do not: art, architecture, and historic traditions all within Old Havana. That said, we reject the idea of turning our historic centre into a theme park and novelty show. ${ }^{5}$

Santería stands out prominently as one of these historic traditions, but not all its practitioners approve of its new, marketable face. Some have joined together to rediscover a more traditional, African form of the religion by researching its historical foundations and refusing outright to perform its sacred arts on the folklore stage. Through this commitment, they aim to 'rescue' their tradition by closely defining its spiritual and social teachings, while staying loyal to community interests and solidarities.

It is tempting to take sides in the debate: is an expanding entertainment industry fundamentally damaging Santería's role in community welfare, or is resistance to commodification effectively maintaining the religion's spiritual efficacy and capacity for social support among its followers? I wish to explore the middle ground between these antitheses through a series of short narrative anecdotes. Drawing from Fernando Ortiz I will suggest that a less essentialised reading of the situation may be possible when theorised in terms of transculturation.

Ortiz developed the concept of transculturation in 1940 to account for the interpenetration of Spanish and African cultural influences in Cuban national identity. The dominant model of crosscultural contact at the time was acculturation, which predicted the inevitable assimilation of non-industrial societies into the currents of an expanding European political economy. Ortiz's transculturation, on the other hand, acknowledged the ongoing influence of the customs, traditions, and cultures of all participants in scenarios of cross-cultural contact and exchange.

By examining the issue of religious commercialisation through the analytic lens of transculturation I hope to show that Santeríaís predicament is conditioned not by tourism or tradition alone but by a convergence of distinct cultural and economic values in collaborative activities. In the negotiated episodes of daily life, the effects of film contracts and cabaret performances on religious communities are only one half of the story; the other half is about the attempts of religious practitioners to assert their own influences and values in the collaborative projects that result. The activities of Miguel in Old Havana are a good example of this. His skilful orchestration of 
presentations and meetings to accommodate the diverse needs of foreign film makers, percussion students, aspiring initiates, and his local religious following show an interpenetration of commercial, community, and personal objectives. The convergence of these objectives in common activities shows transculturation in motion.

\section{SACREDTHEATRE:THE} TRANSFORMATIONOF TRADITION

\begin{abstract}
Although I'm seated in the sixth row of the open-air amphitheatre, I can see the stage clearly. The batá drummers are at the back of the stage, the singer (akpón) to their left, and the dancers, all women, in front. Dressed from head to toe in the white robes of recent Santeria initiates (iyawo), the eight dancers move in a slow, graceful circle to the rhythm of the goddess Yemayá, '... asesu Yemayá, Yemayá olodo, olodo Yemayá...' The akpón's phrase is repeated in soothing tones by the dancers.
\end{abstract}

The rhythms gradually build tension and the phrases of the call and response songs become shorter and more energetic: ' ... tsikini ... a la modanse ...' The dancers have broken from the circle and are stepping quickly now, the largest batá drum (iyá) filling the electrified evening air with torrid, thunderous improvisations. One of the dancers near the front of the stage starts to convulse, eyes rolled back, taken by the goddess Yemayá. The other dancers catch her before she falls; she regains balance and starts to spin faster and faster: '... yaale yaalu ma o ...' The three batá drums are locked into a controlled, very rapid polyrhythm, punctuated by the calls of the iya and responses of the second drum, itotele. The spinning dancer collapses and hits the floor.
The show is over and the audience is on its feet applauding. The lights come up and the air gradually fills with the sound of European conversations: 'Where can I get a recording of this music?' 'Grabaste esa última parte con la cámera?' 'A quelle heur vient l'autobus de l'hotel?' Slowly the crowd disperses, most of it getting onto the tour bus. 'The energy was incredible! What beautiful costumes ...'

\section{Personal Diary, Santiago de Cuba 2002}

Theatrical renderings of sacred ritual are commonplace wherever there are hotels and cabarets in Cuba, and many foreigners (myself included) invest energy, money and time in learning this kind of religious music and dance. But according to the artistic director of the Cuban National Folklore Ensemble, Rogelio Martínez Furé, the material performed and the knowledge taught are often something other than they appear:

There are people who hardly know how to sing or play, yet they give music and dance classes to foreigners. And what they transmit is a popularised pseudotradition that is deformed and deforms ... The temptation to earn easy money has captured many opportunistic hearts ... since the good grain is mixed in with the dirt, they take advantage of the historical moment to prey on traditional culture for personal gain. ${ }^{6}$

Martínez Furé's point is not that the folkloric representation of sacred practices does them harm, but rather that the misrepresentation of religious traditions by untrained performers for unknowing audiences and students ultimately deforms their integrity: 
Unfortunately, most of these young performers know very little about these traditions because they're more focused on earning money. I call this 'the jineterismo [hustling/ pimping] of pseudo-culture.' We have a serious problem here with the commercialisation of music and religion. Foreigners come to buy religious knowledge and experience, and many babalawos [priests of Ifá, a divination tradition associated with Santería] will do anything for dollars. ${ }^{7}$

For Martínez Furé, the integrity of Afro-Cuban religions has been eroded with commodification. It is an opinion shared by Miguel Barnet, who notes that the traditional practice of handing down sacred knowledge within religious families has been undermined by a new tendency to reveal secret information to paying customers. He calls this the 'horizontalisation' of what was previously a more structured, linear process of religious education. ${ }^{8}$ The changing material conditions brought by an opening economic climate, it seems, are causing cultural transformations.

\section{GRASSROOTSRESISTANCE:THE TRANSCENDENCEOFTRADITION}

It has been a busy weekend in the templehouse. There were over thirty people involved in the ceremonies last night, and many of the guests were still here this morning. After lunch seven bata drummers came to the temple-house and we prepared the drums for tonight's ceremony. More drummers gradually arrived, and by $4 \mathrm{pm}$ there were eighteen omo aña [initiated drummers] chatting in the street outside the templehouse. That's when Lázaro showed up. He said his group was hired for the night to play in the rooftop bar of the Hotel Inglaterra. He needed six drummers and could pay each of them fifteen US dollars. [About four times what a drummer typically earns in a religious ceremony.] Since only four of five drummers are needed to alternate on the three batá drums, I expected that Lázaro would take at least six of the eighteen drummers with him. But only one went. I asked some of the others why they didn't take the opportunity. One of them replied: 'We need money to survive, but we need el santo ['the saint', used here to mean 'religion'] even more'.

Personal Diary, Havana 2001

The decisions of religious drummers to accept or reject these kinds of commercial opportunities usually involve more than a utilitarian calculation of profits. Such decisions are also based on community loyalties, fear of rebuke from religious elders, and a sense that the public performance of religious music is simply disrespectful to Santería's spiritual foundations. These concerns can and do lead some musicians and dancers to restrict their performances to sacred contexts.

This is particularly true for members of two Havana grassroots Santería organisations called Ifá Iranlowo and Ilé Tún Tún. Both groups were founded in the early 1990s and share the goal of rediscovering and maintaining a more orthodox, less commercial Santería. They are leading an emerging 'Africanisation' movement within the religion, which Víctor Betancourt - the president of Ifá Iranlowo - describes as 'the restructuring of the Afro-Cuban belief system, the rescue of ancient traditions and cultural roots deformed by syncretism'. ${ }^{9}$

The two organisations demonstrated the depth of their public support during 
the Pope's visit to Cuba in 1998, when they convened over 450 high-ranking practitioners of Santería to lay the preliminary foundations of a unified Church of Santería. ${ }^{10}$ According to Anet del Rey Roa of Havana's Centre for Psychological and Social Research (CIPS), the two organisations' popular backing results primarily from their thorough research of Santería orthodoxy (largely through review of ethnographic data and interviews with religious elders), and their reserved stance toward folkloric performance of religious traditions. ${ }^{11}$ Together with the drummers in the diary excerpt, Ifá Iranlowo and Ilé Tún Tún demonstrate that some practitioners of Santería recognise conflicts between the expanding entertainment industry and the interests of their communities. These conflicts lead many people to subordinate commercial opportunities to religious loyalties.

\section{HIDDENEXCHANGES:THE TRANSCULTURATIONOFTRADITION}

The above scenarios represent diverging responses to an expanding tourist market, which Cuban scholars and religious practitioners have described as cultural transformation on the one hand and cultural resilience on the other. But there exists a wide margin of possibility between the extremes of religious survival versus religious breakdown, and it is in this margin that the mutual influences of tourism and Santería - their transculturations - are most visible. As my teacher Miguel shows in the following narratives, these spaces of interactive mutation are often elusive and hidden from the eyes of actors:

When a film crew arrives from England, Italy, Spain, the US etc, to film the music and dancing of rumba and batá, religion always figures in prominently. Today, the English film crew made Miguel the feature of their documentary. He did an interview in full ceremonial regalia plus a mock consultation with Orula [the Santeria deity of divination]. After his performance I asked Miguel what other babalawos might say if they saw the film, which involved killing a pigeon for Orula.

'Don't worry, it's all an act!' he said. 'I mean, look: this is what I used for Changó [ the deity of thunder and drumming].' He was pointing to a conga drum, over which he'd draped a red cloth, to make it appear as though the container of Changó would appear in a real ceremony. 'And look,' he went on, 'is that Orula?' He was talking about the collection of small seashells held in his palm. Although there were sixteen of them, these were not the cowry shells of Orula. 'Also, I didn't say the real words. Look 'Omi ani wana ... Carlos Maunuel y su Clan ... afri añeñe ... Los Van Van, Isaac Delgado' [names of Cuban pop music groups]. Any babalawo who sees this on TV will laugh and say, 'Oh, that Miguel is a cabrón!'And besides, anyone would do the same for \$200 US.'

I've never heard Miguel justify his actions in such depth, particularly to me, so I was surprised he went into so much detail. And then I realised that there were others in the room, including another babalawo and two elderly priests of Santería. I think the energetic explanation was more for them.

Personal Diary, Havana 2001

In this episode Miguel made much of his skilful construction of an apparently authentic experience out of invented words, objects, and actions, and he identified this accomplishment as the cunning behaviour of a cabrón. But 
babalawos have been strategically guarding sacred information since long before the recent wave of international attention on Cuba. A lack of appreciation for this tradition of selective restraint, particularly if one is attempting to learn information deemed sacred, can be dangerous. The story of Otura Niko, one of the many deified characters who comprises the parables of Ifá divination, expresses this lesson well. The day I was sworn to the batá drums, the story was narrated to me by a babalawo in the city of Santiago de Cuba as follows:

Otura Niko was learning to play the batá drums. He was improving well; so well that his teacher knew that Otura Niko would soon be more proficient than him. One day Otura Niko asked his teacher to give him the final secret rhythm, but his teacher refused. Otura Niko asked again and again until his teacher finally relented, saying, 'Come to my house for dinner tonight and Iill teach you the final lesson'. That night the two sat down to dinner; but only the teacher got back up. He had poisoned and killed his student Otura Niko for trying so hard to take knowledge that can only be given.

As my own proficiency on the batá drums improved, my various mentors and their colleagues made sure I knew this story well. On one occasion, while attending a batá ceremony with a Cuban fellow student, we noticed a number of differences between the way Miguel was playing and the way he had taught us. When we asked him about this he admitted what we had suspected: not only had he taught us an altered version of the rhythm in our drum class, but he had no intention of teaching us the correct version. Then, to our surprise, he congratulated us for learning an important lesson: that experience is the best teacher.

According to Martínez Furé, the pedagogic technique of withholding and disguising sacred knowledge is characteristic of African-based religion in Cuba. ${ }^{12}$ Meaningful lessons are revealed little by little and sometimes not at all, requiring new initiates to learn actively and patiently over a period of time. Time, though, is one of the few things that most foreigners do not have in Cuba, and even the month-long tourist visa has recently become more difficult for North Americans and others to acquire. As a result, foreign students of Santería music and dance, even those who become initiated in the religion, study their material hard but often have no opportunity to test the worth of their knowledge. While Martínez Furé points out the dangers of learning 'deformed' knowledge from unqualified, inexperienced teachers, this second kind of misinformation - the intentional kind - can result from studying with highly experienced teachers.

\section{CONCLUSION}

With copies of their lessons recorded on minidisks and videocassettes, most foreigners return home from Cuba - like the British film crew - satisfied that they got what they came for. In this way, babalawos like Miguel serve the interests of foreign tourists while staying within the boundaries of their religious tradition, and successfully make a living in the process. This synthesis of diverse objectives in ritual performance is an example of transculturation in practice. Seen in this light, Miguel's folkloric performances, and those of thousands of others throughout the island, cannot be 
explained simply in terms of religious breakdown or religious continuity. Instead, they reveal cultural mutations of a new kind that play out according to overlapping local and global scripts. As Sahlins has argued, even the most extreme social adaptations can appear seamless when they make good cultural sense. ${ }^{13}$ And as Ortiz argued over 40 years ago, the maintenance of good cultural sense for all concerned is what characterises even the most extreme transculturations. ${ }^{14}$

This article has attempted to answer an increasingly pertinent question: does the contemporary predicament of Cuban Santería indicate the transformation of religious culture under the influence of an expanding global entertainment industry, or the transcendence of religious culture as it resists commodification? The answer must surely lie between these two extremes, with self-proclaimed ëcabronesí like Miguel and thousands like him, who manage to balance and integrate business with religion. These are the new agents of transculturation: they serve two masters, and in so doing are themselves served by both.

\section{ENDNOTES}

1 Philip A. Howard, Changing History: Afro-Cuban Cabildos and Societies of Color in the Nineteenth Century, (Baton Rouge: Louisiana University Press, 1998); Fannie Theresa Rushing, Cabildos de Nación y Sociedades de la Raza de Color: Afro-Cuban Participation in Slave Emancipation and Cuban Independence, 1865-1895, Doctoral Thesis, University of Chicago History Department, 1992.

2 Adrian H. Hearn, 'Afro-Cuban Religions and Social Welfare: Consequences of Commercial Development in Havana. Human Organization', Human Organization 63 (1): in press, 2004;
Haroldo Dilla Alfonso, Armando Fernández Soriano and Margarita Castro Flores, 'Movimientos Comunitarios en Cuba: Un Análisis Comparativo', Cuban Studies 28: 100-124, 1999.

3 Rogelio Martínez Furé, 'Cubanía', in Bohemia (La Habana: 2001, no. 10), pp. 10-12; Miguel Barnet, interviewed March, 2002; Carlos Moore, Castro, the Blacks and Africa, (Los Angeles: University of California Press, 1989).

4 Robin Moore, Nationalizing Blackness: Afrocubanismo and Artistic Revolution in Havana, 1920-1940, (Pittsburgh, PA: University of Pittsburgh Press, 1997).

5 Leal, interviewed April 2002.

6 Martínez Furé, 'Cubanía', pp. 11 -12.

7 Martínez Furé, interviewed May 2001.

8 Miguel Barnet, interviewed March 2002.

9 Víctor Betancourt, El Babalawo: Médico Tradicional, (La Habana: Página Regional, 1995), p. 4.

10 Miguel Ramos, Ashé in Flux: the Transformation of Lukumí Religion in the United States. Paper presented to the 47th Annual Conference of the Centre for Latin American Studies, University of Florida, 1998.

11 Anet del Rey Roa, interviewed May, 2002.

12 Martínez Furé, interviewed May, 2001.

13 Marshall Sahlins, Historical Metaphors and Mythic Realities, (Ann Arbor: University of Michigan, 1981), p. 50.

14 Fernando Ortiz, Cuban Counterpoint: Tobacco and Sugar, (Durham and London. Duke University Press, 1940/1995). 